\title{
MIR320A Gene
}

National Cancer Institute

\section{Source}

National Cancer Institute. MIR320A Gene. NCI Thesaurus. Code C81798.

This gene is involved in the regulation of gene expression and plays a role in the development of cholangiocarcinoma, acute myeloid leukemia and sickle cell disease. 